\title{
Utilization of coconut shells in the manufacture of appropriate goods
}

\author{
Mimpin Ginting ${ }^{1 *}$, Minto Supeno ${ }^{1}$ \\ ${ }^{1}$ Department of Chemistry, Universitas Sumatera Utara, Medan, Indonesia \\ *Email: mimpinginting@usu.ac.id
}

\begin{abstract}
Coconut shell inside is hard or very hard polymer, because of the composition of lignin > cellulose, such material s not good as a TV antenna. Because if given electromagnetic waves there will be vibrations of molecules $>$ ure rotation. To overcome this, the lignin concentration is reduced so that the concentration of lignin <cellulose can be used as a TV antenna, HP, because such material has become soft material. This combination of soft $>$ hard polymers can theoretically be used for the purpose of detecting earthquakes, satellite etc. If the coconut is shaken, there will be ripples of coconut water to the ears, facts thus showing that the coconut shell has gaps or pores which carries waves of coconut water to the ears, which come out through the interface of lignin cellulose. The initial symptoms thus mean that the coconut shell can reflect and absorb waves. The advantages of this antenna can close up more clear, clear, cool clearer eyes and reception, can be used in the lowlands, highlands and at the bottom sea, this antenna is very good performance for high frequencies, can close up clearer, clear, cool in the eyes and voice reception clearer.
\end{abstract}

Keywords: Shell antenna, UHF antenna, polymer material

\begin{abstract}
Abstrak
Batok kelapa didalam merupakan polimer hard atau very hard, karena komposisi lignin > sellulosa, material demikian tidak baik sebagai antena TV. Karena jika diberi gelombang elektromagnetik akan terjadi vibrasi molekul >> rotasi murni. Untuk mengatasi ini maka konsentrasi lignin diturunkan sehingga konsentrasi lignin < sellulosa maka dapat digunakanm sebagai antena TV, HP, karena material demikian telah menjadi material soft. Kombinasi polimer soft > hard ini secara teori dapat digunakan untuk keperluan mendeteksi gempa bumi, satelit dll. Apabila kelapa digoncang-goncang maka akan terdengar riak air kelapa ke telinga,fakta demikian menunjukkan bahwa tempurung kelapa mempunyai celah atau pori-pori.pori-pori ini yang membawa gelombang air kelapa ketelinga,yang keluar melalui antar muka lignin selulosa.Gejala awal demikian mengartikan bahwa tempurung kelapa dapat memantulkan dan menyerap gelombang. Keunggulan antena ini dapat close up lebih jelas, bening, sejuk dimata dan penerimaan suara lebih jelas, dapat digunakan di dataran rendah, tinggi dan di dasar laut, antena ini sangat baik kinerja untuk frequensi tinggi, dapat close up lebih jelas, bening, sejuk dimata dan penerimaan suara lebih jelas.
\end{abstract}

Kata kunci : Antena batok, antenna UHF, material polimer

\section{PENDAHULUAN}

Batok kelapa didalam merupakan polimer hard atau very hard, karena komposisi lignin > sellulosa, material demikian tidak baik sebagai antena TV. Karena jika diberi gelombang elektromagnetik akan terjadi vibrasi molekul 》 rotasi murni. Untuk mengatasi ini maka konsentrasi lignin diturunkan sehingga konsentrasi lignin < sellulosa maka dapat digunakanm sebagai antena TV, HP, karena material demikian telah menjadi material soft. Kombinasi polimer soft $>$ hard ini secara teori dapat digunakan untuk keperluan mendeteksi gempa bumi, satelit dll.

Apabila kelapa digoncang-goncang maka akan terdengar riak air kelapa ke telinga,fakta demikian menunjukkan bahwa tempurung kelapa mempunyai celah atau pori-pori.pori-pori ini yang membawa gelombang air kelapa ketelinga,yang keluar melalui antar muka lignin selulosa.Gejala awal demikian mengartikan bahwa tempurung kelapa dapat memantulkan dan menyerap gelombang (Supeno, 2007) kekerasan pada tempurung kelapa tua meningkat pada tempurung kelapa terdapat daerah antar muka lignin selulosa. Yang dapat dipandang 2 buah plate 
sejajar yang berbeda potensialnya,atau antar muka terjadi pertemuan kedua potensial yang berotasi.Jika diberikan gelombang elektromagnetik molekul polimer akan bervibrasi dan berotasi.Jika medan listrik konstan diberikan pada sample,tingkat energy bergeser sejauh yang ditentukan oleh besaran momen dipol molekul,pemisahan keadaan oleh medan listrik (efek stark) (Supeno, 2007).

\section{METODE PELAKSANAAN}

\subsection{Alat Percobaan}

Panci aluminium, plat penjepit tiang, tempat tiang antenna, pipa aluminium, reflector, ring, baut, mur, kabel

\subsection{Bahan Percobaan}

Bahan dasar pembuatan antenna TV ini adalah batok kelapa.

\subsection{Prosedur Percobaan}

Kelapa tua yang telah dipecah dua dan dibersihkan dari daging buah maupun sabutnya selanjutnya digosok mengggunakan gerenda atau kertas gosok.Tempurung demikian direndam dengan menggunakan $\mathrm{NaOH}(1-5) \mathrm{M}$ selama (1-3) hari pada suhu $30-40^{\circ} \mathrm{C}$. Perendaman ini berguna untuk memperbesar pori-pori batok kelapa selanjutnya tempurung kelapa direbus pada aquadest mendidih selama (1-24) jam guna menurunkan lignin sampai $(20-23,5) \%$.Tempurung kelapa dikeringkan pada terik matahari sehingga kadar air mencapai 0,01-2\% selama (1-5) hari.Tempurung kelapa yang ada matanya (bagian atas) dilubangi menggunakan bor untuk tempat baut dan mur yang berjarak 1$2 \mathrm{~cm}$.Dimana baut ini tempat penghubung kapasitor $210 \mathrm{pF}$ dan resistor $470 \mathrm{Ohm}$.Sedangkan bagia belahan tengah diberikan lempengan aluminium berjajar dan dilekatkan dengan lem kayu.Antena tempurung kelapa ini sangat baik bekerja pada ferekuensi 400-1000 Mhz dan dapat diatas 1000 MHz,dengan Gain antenna berada pada kisaran 9,08-11,2 dB.Sehingga antenna ini baik untuk ultra high frequensi (UHF) dan radius penerimaan mencapai $180 \mathrm{Km}$ yang diukur menggunakan metode baring.

\section{HASIL DAN PEMBAHASAN}

Hasil penelitian komposisi tempurung kelapa tua terdiri dari air $(\mathbf{8 , 3 \%})$,abu $(\mathbf{0 , 6 \%})$,lignin $(29,6 \%)$,selulosa $(26,6 \%)$,pentosan $(27,7 \%)$, uronat anhidrat $(3,5 \%)$ dan zat ekstraktif $\mathbf{( 4 , 2 \% ) . B e r d a s a r k a n ~ k o m p o s i s i ~ d i a t a s ~ m a k a ~ t e m p u r u n g ~ k e l a p a ~ d i d o m i n a s i ~ o l e h ~ l i g n i n , s e l u l o s a ~}$ dan pentosa.Struktur tempurung kelapa mempunyai cincin benzene,maka kekerasan pada tempurung kelapa tua meningkat pada tempurung kelapa terdapat daerah antar muka lignin selulosa. Yang dapat dipandang 2 buah plate sejajar yang berbeda potensialnya,atau antar muka terjadi pertemuan kedua potensial yang berotasi.Jika diberikan gelombang elektromagnetik molekul polimer akan bervibrasi dan berotasi.Jika medan listrik konstan diberikan pada sample,tingkat energy bergeser sejauh yang ditentukan oleh besaran momen dipol molekul,pemisahan keadaan oleh medan listrik (efek stark).lignin selulosa mempunyai karbonil (CO) yang spesies isotope dengan spectrum rotasi murni seperti table 1.untuk transisi rotasi murni $12 \mathrm{C} 16 \mathrm{O}$ pada $\mathrm{v}=0$,yaitu :

Tabel 1.Level Transisi rotasi murni C-O

\begin{tabular}{|l|l|l|l|l|l|}
\hline $\mathrm{J} \rightarrow \mathrm{J}+1$ & $0 \rightarrow 1$ & $1 \rightarrow 2$ & $2 \rightarrow 3$ & $3 \rightarrow 4$ & $4 \rightarrow 5$ \\
\hline $\mathrm{v} / \mathrm{MHz}$ & 115,271 & 230,538 & 345,796 & 461,041 & 576,268 \\
\hline
\end{tabular}


Batok kelapa didalam merupakan polimer hard atau very hard, karena komposisi lignin > sellulosa, material demikian tidak baik sebagai antena TV. Karena jika diberi gelombang elektromagnetik akan terjadi vibrasi molekul > rotasi murni. Untuk mengatasi ini maka konsentrasi lignin diturunkan sehingga konsentrasi lignin < sellulosa maka dapat digunakan sebagai antena TV, HP, karena material demikian telah menjadi material soft. Kombinasi polimer soft $>$ hard ini secara teori dapat digunakan untuk keperluan mendeteksi gempa bumi, satelit dll.

\section{KESIMPULAN}

Antena batok merupakan teknologi antena UHF yang original,dihasilkan dari penelitian bersinambung serta pengamatan selama bertahun-tahun. Material polimer alam dari kombinasi softhard yang dapat diandalkan sebagai antena televisi pada radius $180 \mathrm{~km}$,dengan gain antena $11 \mathrm{~dB}$, yang dapat digunakan di dataran rendah ,tinggi dan didasar laut.Antena ini sangat baik kinerja untuk frekuensi tinggi.

\section{UCAPAN TERIMAKASIH}

Penulis mengucapkan terima kasih kepada LPPM USU melalui dana Non PNBP Universitas Sumatera Utara sesuai dengan Surat Perjanjian Penugasan Pelaksanaan Pengabdian Kepada Masyarakat Program IBKIK Tahun Anggaran 2017 Nomor : 3223/UN5.2.3.2.1/PPM/2017, Tanggal 24 Juli 2017.

\section{DAFTAR PUSTAKA}

Attar N, Korkmaz Y. Effect of two light-emitting diode (LED) and one halogen curing light on the microleakage of class V flowable composite restorations. J Contemporary Dent Pract 2007; $8(2): 1-10$.

Supeno, 2007. Bentonit Alam Terpilar Sebagai Material Katalis/Co-Katalis Pembuatan Gas Hidrogen Dan Oksigen Dari Air. Medan. Universitas Sumatera Utara

Supeno, M.., and Siburian, R. 2018. New route: Convertion of coconut shell tobe graphite and graphene nano sheets. Journal of King Saud University - Science. Article in Press.

Supeno, 2003. Analisis Hambatan Karbon Dalam Lingkungan Asam-Basa. Medan. Universitas Sumatera Utara 